\title{
PERANCANGAN SISTEM E-LEARNING BERBASIS ANDROID DENGAN MENGGUNAKAN FIREBASE PADA UNIVERSITAS ADVENT INDONESIA
}

\author{
Hugo Mulana Christon, Elmor Wagiu dan Yulianus Palopak \\ Fakultas Teknologi Informasi, Universitas Advent Indoensia
}

\begin{abstract}
Abstrak
Perkembangan teknologi semakin pesat, terutama pada perkembangan smartphone dan juga media pembelajaran. Dengan adanya teknologi ini, berbagai kegiatan dapat dilakukan dengan cepat dan mudah seperti halnya pada kegiatan proses belajar dan mengajar. Tujuan dari penelitian ini adalah untuk menganalisa serta merancang sebuah sistem E-Learning yang dapat memfasilitasi para mahasiswa dan dosen di Universitas Advent Indonesia (UNAI) untuk dapat melakukan proses belajar dan mengajar dengan mudah. Model waterfall merupakan metode SDLC yang digunakan dalam merancang dan membangun sistem ini. Hasil dari penelitian ini adalah sebuah rancangan aplikasi elearning berbasis Android yang dapat digunakan untuk melakukan tugas seperti login/logout, pergantian password, membuat/menghapus/mengubah kelas dan tugas, chatting, melihat profil pengguna, mengirim pengumuman, dan membuat akun baru. Kedepannya diharapkan aplikasi ini dapat di hubungkan dengan server Universitas Advent Indonesia, dapat memberikan notifikasi tugas sebelum habis masa berlaku tugas tersebut, dan penyempurnaan user interface agar tampilan dapat lebih menarik.
\end{abstract}

Kata-kata kunci: Moodle, Mobile E-learning, Android, Firebase

\section{DESIGN OF ANDROID BASED E-LEARNING SYSTEM USING FIREBASE AT UNIVERSITAS ADVENT INDONESIA}

\begin{abstract}
The development of technology is rapidly inreased, especially in the development of smartphones and also learning media. By technology support, various activities can be carried out quickly and easily as well as the activities of the learning and teaching process. The purpose of this study is to analyze and design an E-Learning system that can facilitate students and lecturers at Universitas Advent Indonesia (UNAI) to be able to carry out the learning and teaching process easily. The waterfall model is the SDLC method used in designing and building this system. The results of this study is an Android based e-learning application that can be used to perform tasks such as login/logout, password change, create/delete/change classes and assignments, chat, view user profiles, send announcements, and create new accounts. In the future, it is expected that this application can be linked to the servers of Universitas Advent Indonesia, can provide task notifications before the expiration of the assignment, and improve the user interface so that the display can be more attractive.
\end{abstract}

Keywords: Moodle, Mobile E-learning, Android, Firebase

\section{Pendahuluan}

E-Learning merupakan salah satu teknologi yang umum digunakan oleh beberapa Universitas. Teknologi yang digunakan adalah untuk mempermudah mahasiswa dan dosen untuk melakukan aktivitas perkuliahan. 
Pada Universitas Advent Indonesia saat ini sudah menggunakan E-Learning sebagai teknologi pembelajaran yakni dengan menggunakan aplikasi Moodle. Penggunaan E-Learning ini masih terbatas pada kegiatan umum seperti pemberian dan pengumpulan tugas, membuat kuis secara online, dan juga chatting yang walaupun masih minim dilakukan oleh pengguna. Belum semua mahasiswa dan dosen yang menggunakan sistem tersebut sehingga mengakibatkan proses pengumpulan tugas ataupun kegiatan yang lain sering terlalaikan. Akses terhadap sistem selama ini dilakukan menggunakan perangkat komputer maupun laptop melalui web browser sehingga hanya dilakukan pada waktu-waktu tertentu saja. Penggunaan smartphone yang sudah marak digunakan secara umum baik oleh dosen maupun mahasiswa dapat dimaksimalkan juga salah satunya untuk mengaKses sistem e-learning.

Menurut Yuniati yang dikutip oleh Rahmelina (2011), handphone yang awalnya hanya digunakan untuk kegiatan komunikasi seperti sms, telepon, atau internet dapat manfaatkan menjadi alat belajar lengkap yang berisi materi perkuliahan. Pemanfaatan smartphone untuk mengakses mobile e-learning berbasis Android diharapkan dapat membantu mahasiswa dan dosen dalam melakukan kegiatan perkuliahan seperti membuat/menghapus/mengubah kelas dan tugas, chatting antar mahasiswa maupun dengan dosen, mengirim pengumuman, dan membuat akun baru. Dengan menggunakan perangkat mobile maka akses terhadap e-learning dapat dilakukan dengan mudah dan cepat serta dapat dilakukan pada setiap kesempatan yang ada. Aplikasi $e$-learning tersebut juga dapat dilengkapi dengan sistem alarm pengingat sehingga memudahkan penggunanya untuk mengingat kegiatan-kegiatan yang sudah terjadwal. Hal tersebut diharapkan dapat meningkatkan jumlah pengguna sehingga semakin lama kegiatan belajar mengajar melalui e-learning dapat lebih maskimal.

\section{Tijauan Pustaka \\ Android}

Menurut Tutorials Point (https://www.tutorialspoint.com), Android adalah sebuah sistem operasi yang berbasis linux digunakan untuk perangkat seperti smartphone dan tablet.

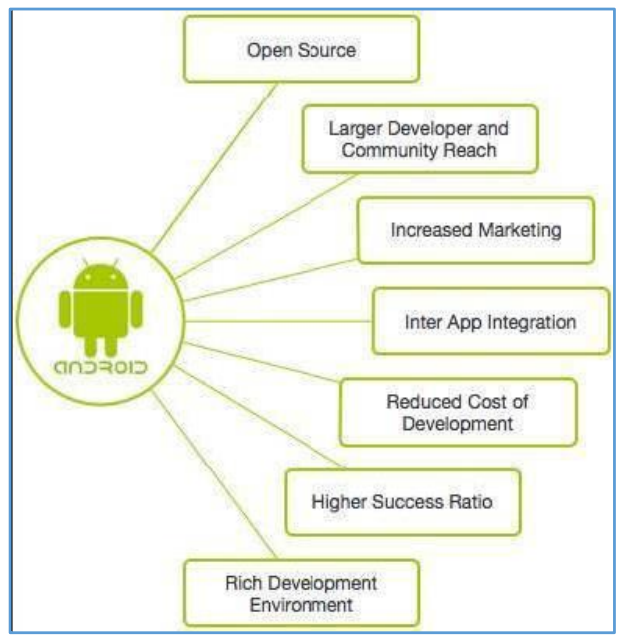

Gambar 1 Fitur Android (https://www.tutorialspoint.com)

Android sendiri menawarkan pengembangan aplikasi untuk perangkat mobile yang berarti develelopers harus membuat aplikasi Android saja, dan aplikasi yang dijalankan harus dapat digunakan di seluruh perangkat yang menggunakan Android sebagai sistem operasi.

Menurut Tutorials Point (https://www.tutorialspoint.com), Android memiliki beberapa keunggulan yang di antaranya menawarkan tampilan antar muka yang menarik, menggunakan media penyimpanan dan relasi database yang ringan serta dapat menlakukan berberapa tugas secara bersamaan. Adapun sistem operasi Android merupakan sekumpulan komponen perangkat 
lunak yang dibagi menjadi 5 bagian cabang dan 4 bagian utama seperti yang ditunjukan pada gambar 2 di bawah ini.

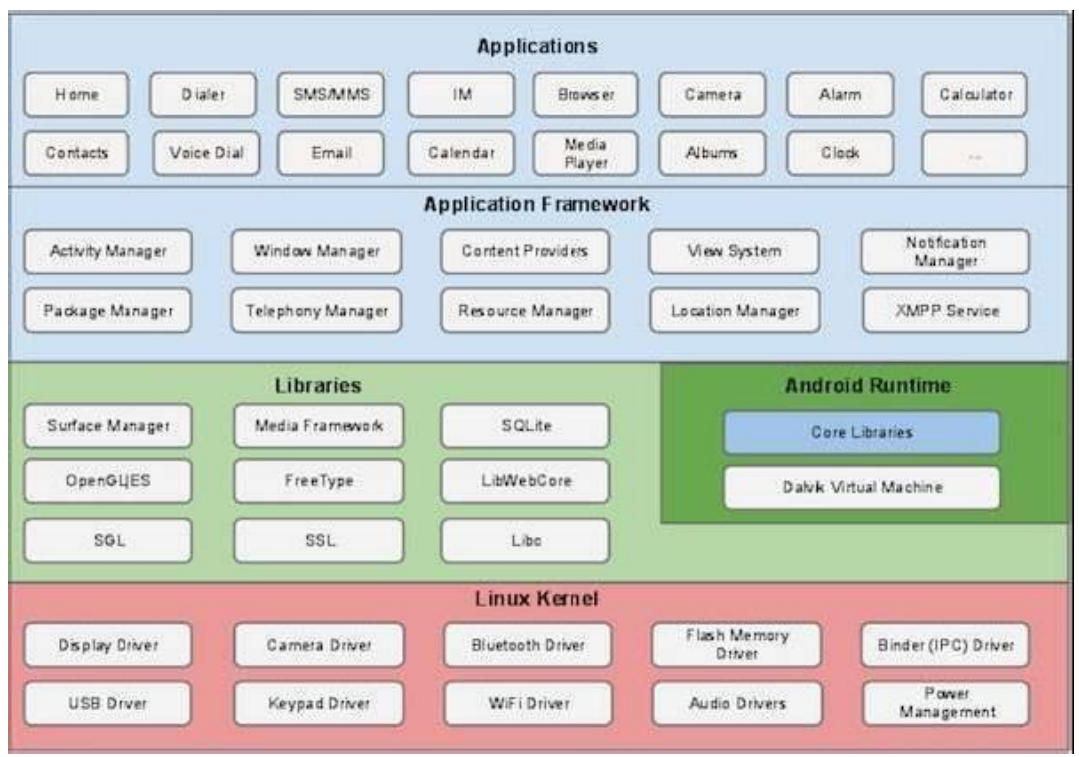

Gambar 2 Arsitektur Android (https://www.tutorialspoint.com)

\section{E-Learning}

Menurut Boban Vesin et al. (2017), istilah E-Learning ada sejak 1999 bersamaan dengan istilah "pembelajaran online" dan "pembelajaran virtual". Berdasarkan penggunaan teknologi baru yang memiliki akses online, interaktif, dan terkadang dapat juga dilakukan latihan perorangan melalui internet atau melalu media lainnya seperti TV, CD-ROM, dan sejenisnya. Salah Satu tujuan ELearning adalah pengembangan konten pembelajaran individual, mudah dimengerti dan juga dinamis secara langsung. E-Learning ini dapat digunakan pada saat di luar. kelas. E-Learning ini juga bisa berarti pembelajaran jarak jauh. Saat ini kita telah menyak melihat teknologi dan metode baru yang muncul dan membuat perbedaan dan tantangan yang besar dalam semua jenis pendidikan.

\section{Firebase}

Menurut Google Developers (https://Firebase.google.com) Firebase merupakan sebuah penyimpanan real-time yang menggunakan cloud-hosted database. Data disimpan dalam bahasa program dan dapat menyinkronkan setiap saat kepada pengguna. Pada Firebase semua pengguna dapat berbagi dengan satu real-time database instansi dan dapat dengan otomatis menerima data terbaru.

Selain database, Firebase juga menawarkan beberapa kegunaan lainnya seperti penggunaan authentication agar user dapat melakukan login yang langsung dapat terkoneksi dengan server Firebase, fitur penyimpanan yang dapat digunakan untuk menyimpan gambar, file, dan berkasberkas lainnya, dan juga beberapa fitur lainnya seperti hosting dan functions.

\section{Analisa Dan Perancangan Sistem Analisis Sistem}

Analisis ini dilakukan untuk memahami lebih dalam mengenai kebutuhan sistem baru sehingga dapat mencari tahu apa saja yang dibutuhkan dan tidak dibutuhkan oleh sistem lama. Pada sistem lama, mahasiswa dan juga dosen UNAI mendapatkan beberapa fitur dalam E-learning berbasis web seperti melakukan Login/logout, mengerjakan tugas online tetapi bukan membuat tugas online, melakukan upload/download data buku ataupun tugas serta dapat melakukan chatting dengan dosen ataupun mahasiswa lainnya. Semetara itu, dosen juga dapat melakukan Login/logout, membuat tugas online, upload/download data buku ataupun tugas, chatting dengan mahasiswa ataupun dosen 
lainnya serta dosen dapat mengkoreksi online tugas yang telah dikerjakan mahasiswa dan memberikan penilaian secara langsung.

Setelah mengetahui Kebutuhan sistem E-learning yang lama pada UNAI maka dapat dirancang kebutuhan sistem yang baru dengan menggunakan aplikasi android yang akan mempermudah mahasiswa dan dosen dengan fitur diantaranya: melakukan login/logout, mengirim pesan online dengan user lainnya, mengirimkan permintaan lupa password, menerima push-notification jika menerima pesan, mendapatkan pengumuman, ataupun menerima tugas baru, melakukan upload/download data buku ataupun data tugas lainnya, memberikan gan menerima pengumuman langsung menggunakan fitur push-notification serta melakukan chatting sama seperti dosen dan mahasiswa.

\section{Use Case Diagram}

Pada use case di bawah ini, terdapat tiga aktor yang berperan dalam melakukan kegiatan Elearning UNAI dimana ketiganya diharuskan untuk login terlebih dahulu sebelum mengakses fungsi sistem yang lainnya. Terdapat beberapa fungsi sistem yang dapat diakses oleh user dalam menggunakan aplikasi e-learning tersebut seperti terlihat pada gambar 3 berikut.

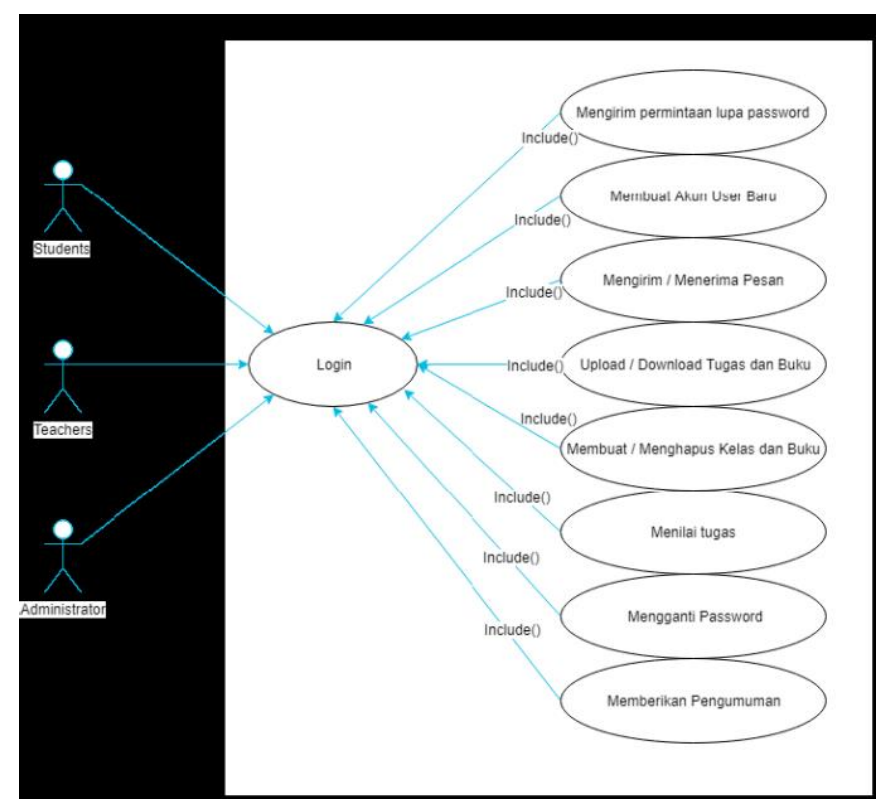

Gambar 3 Use Case Diagram Mobile E-learning UNAI

Adapun penjelasan dari fungsi-fungsi yang ada pada sistem ini seperti yang tertuang dalam usecase sistem adalah sebagai berikut:

a. Mengirim permintaan lupa password. Fungsi ini apat dilakukan oleh semua userdimana userakan diminta untuk memasukkan kembali data nama dan email yang sudah terdaftar. Lalu user dapat melakukan pergantian password pada link yang telah diberikan.

b. Upload/download tugas, dilakukan oleh Dosen dan Mahasiswa. Aktivitas ini dapat terjadi jika sudah login dan dosen telah membuat sebuah tugas baru untuk dikerjakan oleh mahasiswa.

c. Membuat tugas baru. Fungsi ini hanya dapat dilakukan oleh Dosen, dimana dosen memberikan sebuah soal untuk dikerjakan oleh mahasiswa, lalu mahasiswa dapat mengumpulkan tugasnya dengan fungsi Upload/download yang ada

d. Menilai tugas. Fungsi ini juga dilakukan oleh dosen. Ketika siswa telah mengumpulkan tugasnya maka dosen akan dapat mendownload dan memberikan penilaian tugas mahasiswa tersebut.

e. Mengirim/Menerima pesan. Fungsi ini dibuat untuk menjalin komunikasi antara ketiga aktor tersebut. 
f. Mengganti Password. Dapat dilakukan oleh Siswa, Dosen, dan Administrator. Perbedaan administrator dan aktor lainnya adalah administrator dapat mengganti password user apabila diperlukan.

g. Memberikan Pengumuman. Dapat dilakukan oleh Administrator. Administrator dapat dengan umum ataupun spesifik memberikan pengumuman kepada pengguna.

h. Membuat Account Baru. Dapat dilakukan oleh Administrator.

\section{Perancangan Firebase}

Firebase merupakan teknologi web yang dikembangkan oleh Google dengan fasilitas pembuatan authentication, database, penyimpanan, dan lainnya. Pada perancangan firebase dilakukan dengan mengatur autentikasi dimana firebase menyimpan data user berupa Identifier yang berupa email, Password, Created, Signed in, dan User UID. User UID ini akan digunakan untuk menyelaraskan data user dengan authentication sehingga dapat mengambil data nama, fakultas, file, dan data lainnya.

Selanjutnya dirancanga Firebase Database dimana pada aplikasi E-learning ini berfungsi untuk menampilkan data user dan mengambil user profile pada storage dan menampilkan data lainnya. Storage Pada Firebase ini digunakan untuk menampung data-data pengguna seperti gambar profil, file tugas yang telah di upload, dan beberapa data penting lainnya. Chat History tidak tersimpan pada storage Firebase tetapi pada penyimpanan Android dikarenakan akan memakan banyak tempat jika digunakan dalam jangka panjang.

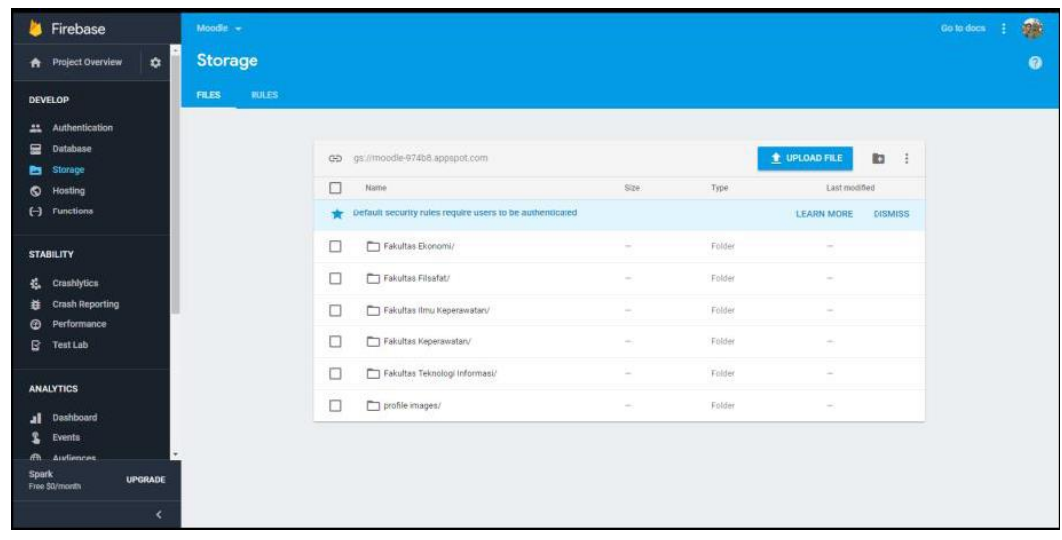

Gambar 4 Firebase Storage sistem

\section{Implementasi Dan Pembahasan}

Hasil dari penelitian ini adalah sebuah aplikasi e-learning berbasis android yang dapat digunakan oleh mahasiswa dan dosen pada Universitas Advent Indonesia dalam mendukung kegiatan belajar dan mengajar. Adapun hasil dari analisa dan perancangan ini dapat dilihat pada fitur-fitur yang ada berikut ini. Pada tahapan awal penggunaan aplikasi diawali dengan halaman muka sebagai halaman pertama untuk user yang baru pertama kali melakukan login pada aplikasi seperti terlihat pada gambar 5. Pada tampilan ini terdapat pilihan untuk melanjutkan login jika sudah memiliki akun dimana selanjutnya user akan diarahkan kehalaman login untuk dapat masuk serta menggunakan aplikasi tersebut. Proses login dapa dilakukan dengan memasukkan id dan password. Jika terdapat kesalahan maka user tidak dapat login. Jika user lupa terhadap password, maka pada halaman user terdapat link untuk reset password. User kemudian akan menerima email untuk melakukan reset password ke alamat email universitas "@unai.edu".

Pada halaman muka juga terdapat link panduan bagi user yang ingin membuat akun pada aplikasi ini. Dalam halaman ini terdapat informasi yang digunakan untuk mengetahui langkahlangkah untuk melakukan registrasi. 


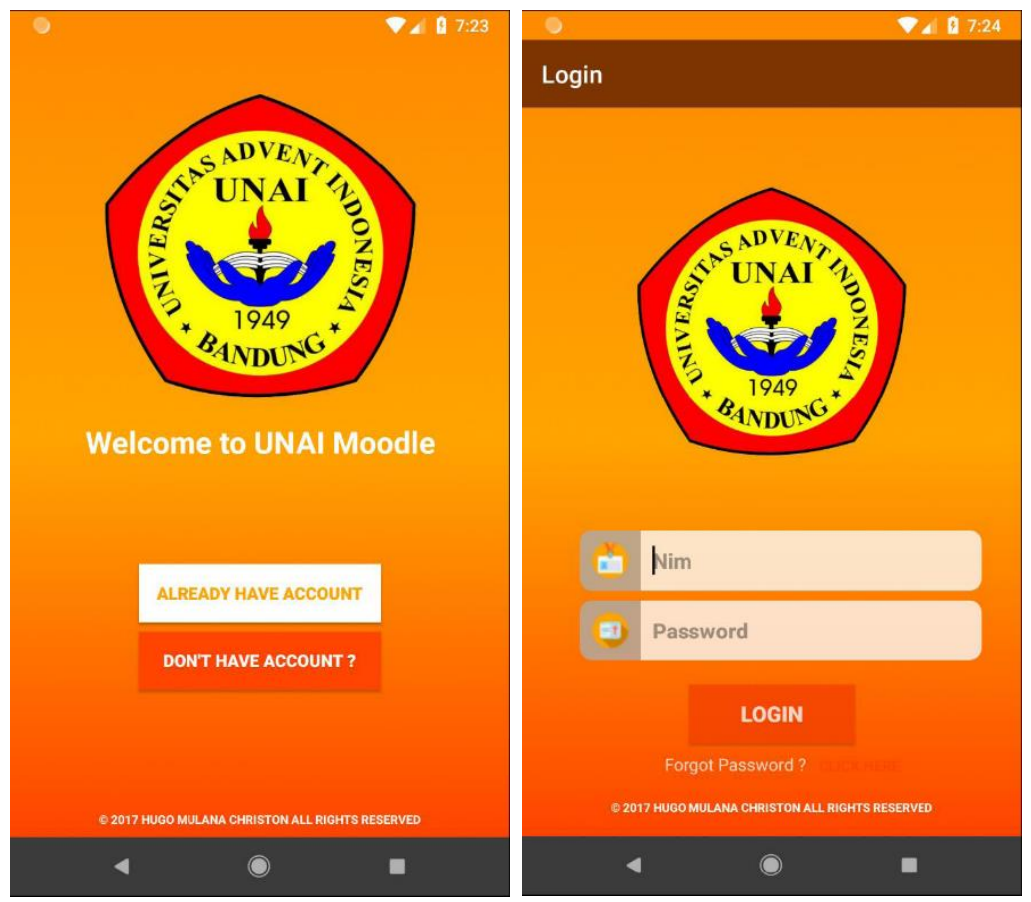

Gambar 5 Halaman muka dan login

Setelah user berhasil login, maka user akan diarahkan ke halaman menu utama seperti terlihat pada gambar 6. Pada halaman menu utama Admin (sebelah kiri) terdapat button Create New Account, Make an Announcement dan Online Messaging. Sedangakan pada halaman menu user biasa (dosen dan mahasiswa) terdapat button Online Messaging dan button Task Assignment.

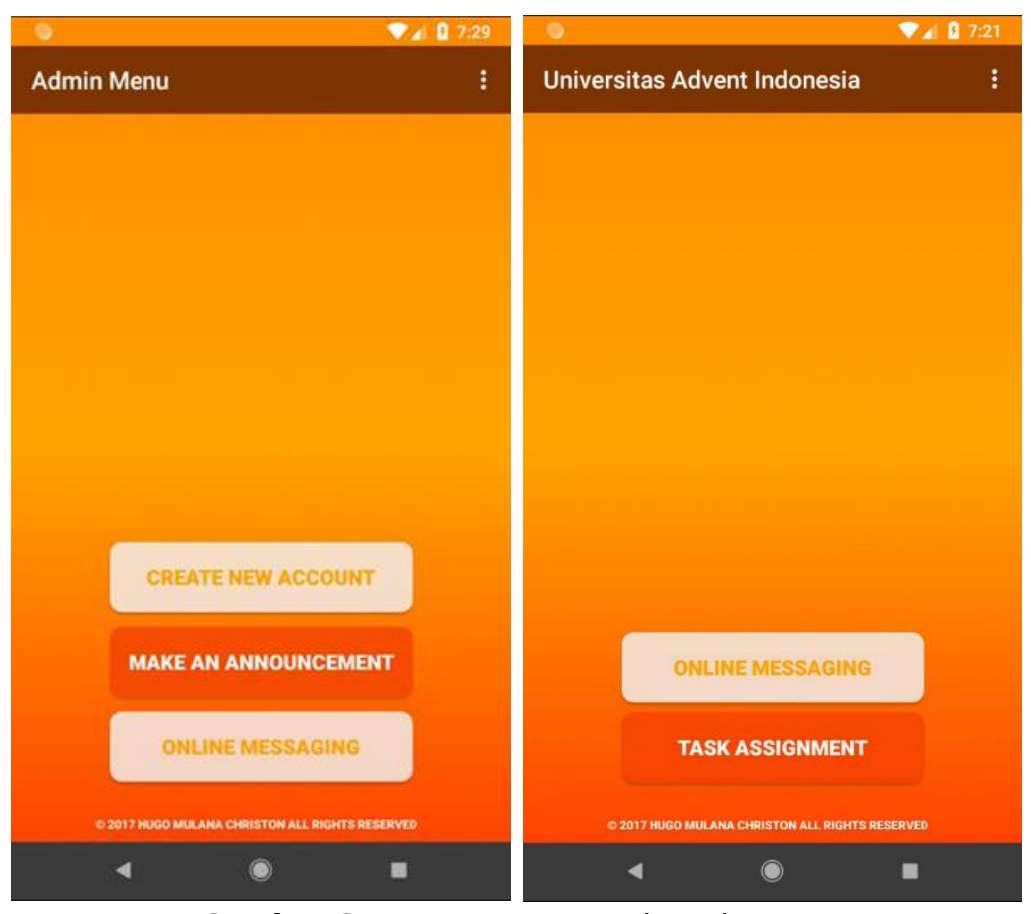

Gambar 6 Main Menu Pages Admin dan User

Tombol Create New Account digunakan untuk mendaftarkan user baru. Sebelum seorang user (mahasiswa atau dosen) dapat login ke sistem maka admin harus membuatkan akun bagi user tersebut dengan mengisi data-data yang dibutuhkan seperti nama mahasiswa maupun dosen, Nomor Induk, Fakultas serta password untuk mengaktifkan akun E-learning android tersebut. 
Tombol Make an Announcement digunakan oleh Admin untuk memberikan pengumuman kegiatan-kegiatan fakultas seperti rapat dosen, chapel fakultas, chapel gabungan, ataupun adanya pertemuan lainnya yang menyangkut kegiatan fakultas, pengumuman sehubungan administrasi, dan pengumuman lainnya yang termasuk di dalam kegiatan kampus Universitas Advent Indonesia. Pengumuman tersebut dapat disampaikan oleh Admin kepada seluruh user secara bersamaan atau kepada user tertentu saja seperti terlihat pada gambar 7.

Untuk tombol Online Messaging dapat digunakan oleh seluruh pengguna untuk mengirimkan pesan secara online kepada useryang lainnya. Fasilitas ini merupakan fasilitas chatting secara bebas antara pengajar dan mahasiswa yang berada di dalam satu fakultas yang sama. Jika user ingin melakukan chatting dengan pengguna di fakultas lain maka user harus menambah pertemanan terlebih dahulu.

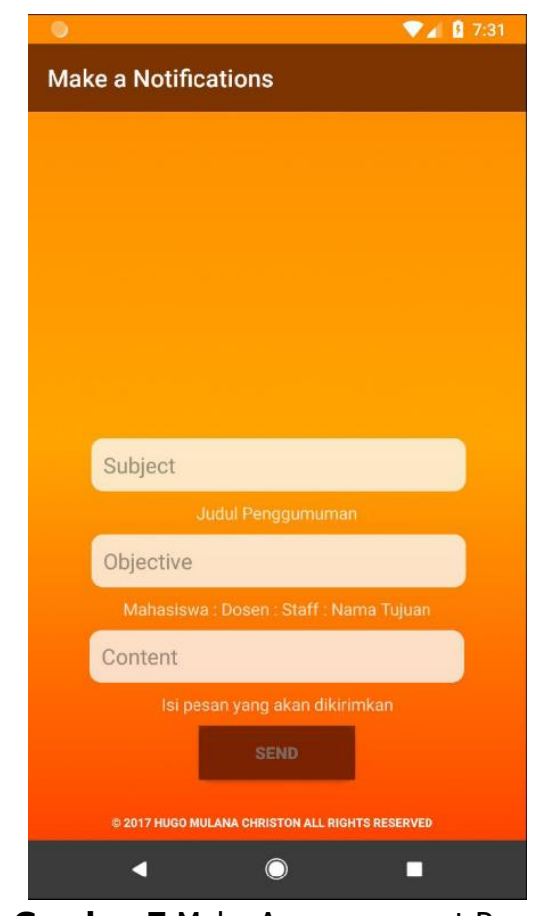

Gambar 7 Make Announcement Page

Tombol Task Assignment digunakan oleh user untuk mengelola kegiatan belajar mengajar. Dosen dapat membuat kelas baru, membuat dan mengirim tugas kepada mahasiswa peserta kelas, mengupload buku serta membuat dan menilai kuis. Apa yang kerjakan dan diupload oleh dosen akan dapat dilihat dan dikerjakan oleh mahasiswa melalui akun mereka masing-masing. Seorang dosen yang mengajar akan membuat kelas baru untuk satu matakuliah tersebut dengan enrolment key sebagai kata kunci yang akan digunakan oleh peserta kelas untuk dapat bergaung ke dalam kelas tersebut. Hal ini ditujukan untuk menghindari supaya mahasiswa yang tidak mengikuti kelas tersebut tidak dapat membuka dengan sembarangan.

Selanjutnya setelah terbentuk kelas beserta dengan pengikut kelasnya, maka dosen akan mengupload buku atau materi perkuliahan dimana semua peserta kelas dapat memilih dan megunduh materi yang ada. Dalam aktivitas ini, dosen dapat melakukan peruahan/penghapusan/pengunduhan buku, sedangkan mahasiswa hanya dapat mengunduh buku tersebut. Dosen kemudian dapat mengupload tugas yang disertai dengan batas pengumpulan tugas tersebut seperti terlihat pada gambar 8. Pada fungsi ini terdapat beberapa fitur yang dapat digunakan seperti melihat deskripsi tugas, mengunduh tugas, melihat mahasiswa yang sudah mengumpulkan tugas, dan mengunduh tugas yang telah dikumpulkan oleh mahasiswa. 


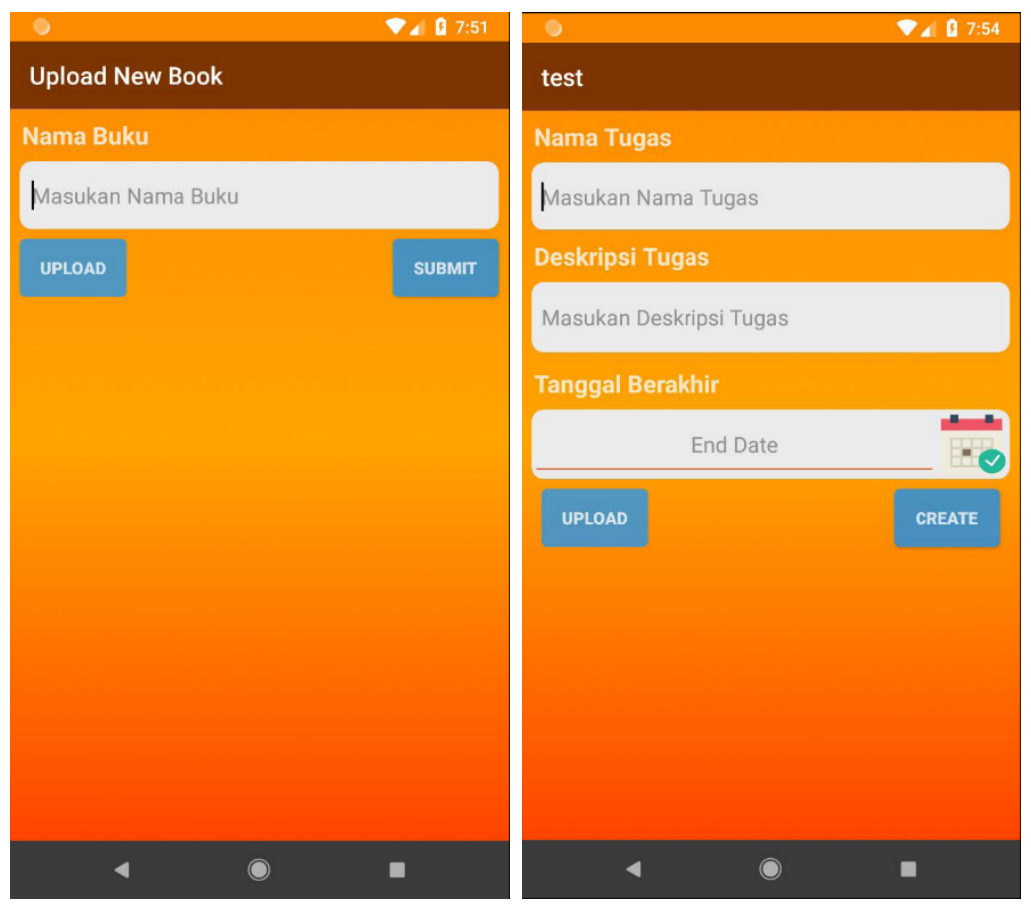

Gambar 8 Book Upload and Task Create Page

Kegiatan ujian seperti kuis juga dapat dilakukan melalui aplikasi e-learning. Dosen dapat membuat soal kuis lalu kemudian mengupload kuis tersebut ke aplikasi e-learning. Mahasiswa yang sudah mendaftar pada kelas tersebut akan dapat membuka serta mengerjakannya secara online. Hasil kuis tersebut akan dinilai secara online oleh dosen yang bersangkutan. Ketika mahasiswa telah mengumpulkan tugas dan mengirimkannya, maka dosen dapat memberikan nilai. Nilai yang diberikan akan dapat terlihat pada halaman pemilihan tugas mahasiswa dan juga halaman pemilihan mahasiswa di dalam tugas ini. Dalam aktivitas ini, dosen dapat membuat kuis baru dan menghapusnya. Sedangkan mahasiswa dapat melihat daftar kuis yang telah dibuat dan melihat nilai yang telah diberikan, seperti terlihat pada gambar 9.

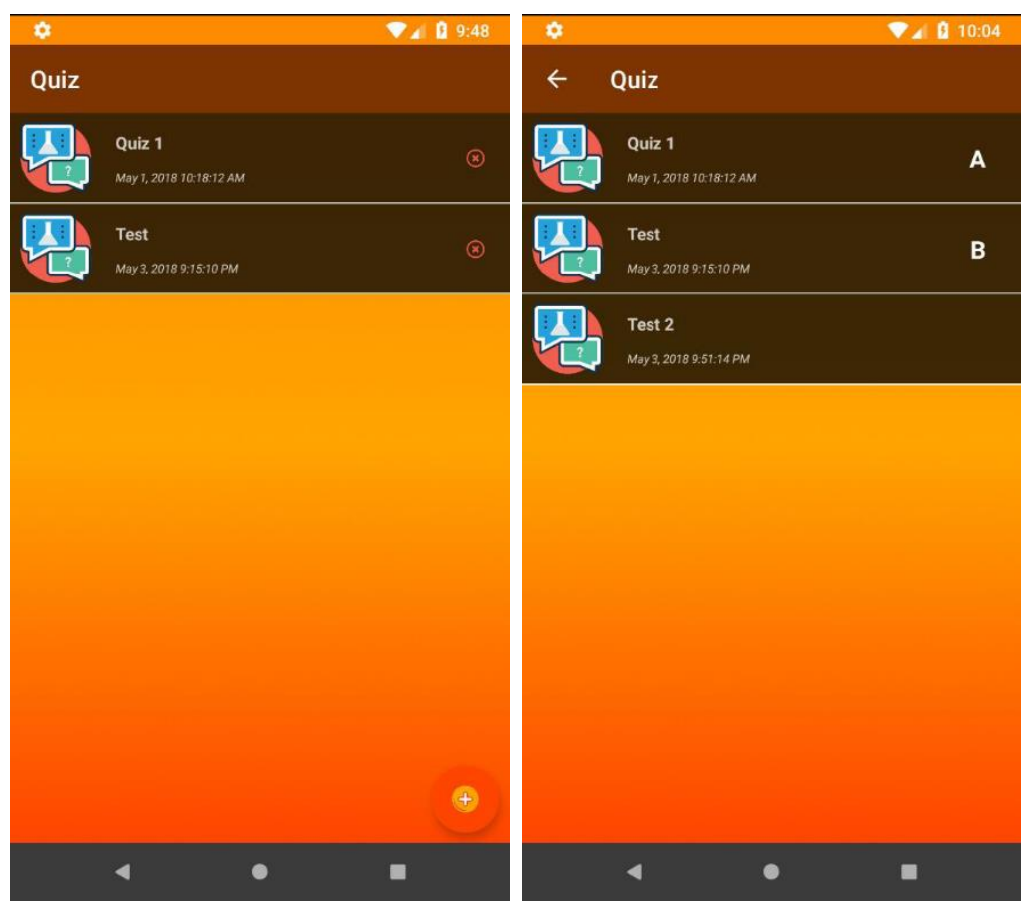

Gambar 9 Quis selection page. 


\section{Kesimpulan dan Saran}

Dari hasil analisa dan perancangan aplikasi sistem e-learning di Universitas Advent Indonesia didapati bahwa aplikasi ini dapat digunakan pada aplikasi mobile berbasis android. Aplikasi berbasis Android ini dapat digunakan oleh user-user yang ada untuk melakukan tugas seperti login/logout, membuat akun baru, membuat/menghapus /mengubah kelas dan tugas, chatting, membuat dan mengupload serta memberi penilaian pada kuis, mengirim pengumuman, dan mahasiswa dapat mengerjakan kuis, mengumpulkan tugas serta menguduh buku pelajaran. Aplikasi mobile learning berbasis Android ini dapat diintegrasikan dengan email UNAI untuk menerima kode penggantian password user. Aplikasi ini masih memiliki banyak kekurangan yang harus diperbaiki ataupun ditambahkan antara lain dimasa yang akan datang seperti fitur notifikasi saat tugas akan expired, terkoneksi dengan sistem dan database online UNAI serta penyempurnaan user interface sehingga lebih baik dan user friendly.

\section{Referensi}

1. Google Developers. (2017). Firebase Realtime Database. Diambil kembali dari https://firebase.google.com: https://firebase.google.com/docs/database/

2. Liranti Rahmelina. Perancangan Mobile Learning Berbasis Android Pada Mata Kuliah Sistem Operasi Di Stmik Indonesia Padang Jurnal Informatika Vol. 11, No. 2 Juli 2017

3. Milićević, A. K., Vesin, B., Ivanović, M., Budimac, Z., \& Jain, L. C. (2017). E-Learning Systems Intelligent Techniques for Personalization.

4. Tutorials Point. (2017). Android Architecture. Diambil kembali dari www.tutorialspoint.com: https://www.tutorialspoint.com/android/android_architecture.htm

5. Tutorials Point. (2017). Android Overview. Diambil kembali dari www.tutorialspoint.com: https://www.tutorialspoint.com/android/android_overview.htm 